\title{
UNDUE PROCESS: CONGRESSIONAL REFERRAL AND JUDICIAL RESISTANCE IN THE SCHIAVO CONTROVERSY
}

\author{
Adam M. Samaha*
}

The congressional response to the Schiavo controversy was both extraordinary and feeble. It surely was exceptional in its speed and specificity. An Act for the Relief of the Parents of Theresa Marie Schiavo ${ }^{1}$ was introduced and approved within a weekend-just days after the feeding tube was removed from Schiavo's body, and only a month after her husband obtained a state court order for that purpose. ${ }^{2}$ The legislation, moreover, could not have been more targeted. The statute's content followed its title, granting certain litigation privileges to the parents and Schiavo alone. Congress had legislated in a one-case-only fashion before, of course. ${ }^{3}$ But private bills tend to resolve controversies. The Schiavo Act, even on its broadest conceivable reading, could do nothing to settle the dispute it addressed. It was meant to unsettle the situation, which the federal courts promptly refused to do.

This kind of congressional action-dealing with a single private dispute and disrupting prior judicial conclusions without implementing new substantive law -is unlikely to recur with any frequency. The Act was more high drama than emerging model. And it is surprisingly difficult to tell whether the federal courts legitimately avoided a more thorough evaluation of the parents' claims. The constitutionality of the Act is open to good-faith dis-

* Assistant Professor, University of Chicago Law School. Thanks to Douglas Baird, Emily Buss, Dan Farber, Saul Levmore, Cara Robertson, Lior Strahilevitz, David Strauss, Cass Sunstein, and Adrian Vermeule for their comments. Shane Davis provided helpful research assistance.

1. Pub. L. No. 109-3, 119 Stat. 15 (2005).

2. See In re Guardianship of Schiavo, No. 90-2908-GD-003, 2005 WL 459634, at *2 (Fla. Cir. Ct. Feb. 25, 2005). A similar order issued five years earlier and was affirmed, see In re Guardianship of Schiavo, 780 So. 2d 176, 177 (Fla. Dist. Ct. App. 2001), but further litigation and legislation kept Schiavo alive, see Bush v. Schiavo, 885 So. 2d 321, 32628 (Fla. 2004).

3. See infra note 28 (discussing private bills). 
agreement. ${ }^{4}$ So it could be that the decision costs associated with analyzing the constitutional question at this late date are not worth the value of knowing the right answer.

This concern about decision costs is linked to a much larger problem, however-a problem fortuitously central to a sound evaluation of the Schiavo Act, and essentially unexplored by commentators. The issue is "undue process" in government decision making. We know that process can be too costly as a matter of policy. Decision costs are just as real as error costs, and there is a well-understood difference between maximizing process and optimizing process. ${ }^{5}$ But is excessive process, like inadequate process, a constitutional problem? For all government institutions and for every threatened private interest? Are courts appropriate agents for policing undue-process violations? Despite its impressive peculiarities, passage of the Schiavo Act is an appropriate occasion on which to ask these questions.

\section{WHAT CONGRESS DEMANDED}

The content of the Schiavo Act was, in many ways, trivial. This fact hardly penetrated the intense public debate about the proper outcome of the dispute-whether Schiavo, who had been diagnosed as stranded in a persistent vegetative state for years, should die quickly in accord with her husband's position; or whether she should remain alive and attached to a feeding tube in the hope of some improvement in her condition, as her parents requested. The Act's modest objective nonetheless affects an evaluation of its lawfulness.

Congress offered no new claim on which Schiavo or her parents could obtain a judicial remedy. The Act was perfectly explicit on this point. It was to have no effect on substantive law. ${ }^{6}$ Nor did the statute direct courts to reach a congressionally

4. See Michael P. Allen, Congress and Terri Schiavo: A Primer on the American Constitutional Order?, 108 W. VA. L. REV. (forthcoming 2006) (manuscript at 8); Steven G. Calabresi, The Terri Schiavo Case: In Defense of the Special Law Enacted by Congress and President Bush, 100 Nw. U. L. REV. 151,153 (2006).

5. See infra text accompanying notes $54-59$.

6. See $\S 5,119$ Stat. 15 ("Nothing in this Act shall be construed to create substantive rights not otherwise secured by the Constitution and laws of the United States or of the several States."); see also id. \$ 1 (conferring subject-matter jurisdiction to adjudicate claims alleging that Schiavo's rights had been violated "under the Constitution and laws of the United States"). Other sections of the Act prohibited interpretations that would confer additional jurisdiction to consider assisted suicide cases, see id. $\$ 6$, disclaimed precedential status for future legislation (for whatever practical value that might have), see id. \& 7, held harmless rights under the Patient Self-Determination Act of 1990, see id. 
favored result under existing law. Judges were no less and no more free after the Act to identify, interpret, and apply substantive federal law. The Act did grant a federal district court jurisdiction to "hear, determine, and render judgment" on a set of federal claims by or on behalf of Schiavo. 'But in isolation, this jurisdictional grant was superfluous. The U.S. Code already conferred general federal question jurisdiction on the federal district courts. "And while the Act sternly announced that the district court "shall issue such declaratory and injunctive relief as may be necessary to protect the [relevant] rights of Theresa Marie Schiavo," this command applied only "[a]fter a determination of the merits" and it added little if anything to the court's preexisting remedial powers and obligations. ${ }^{18}$ So the Schiavo Act had nothing important to say about original jurisdiction, substantive law, or judicial remedies.

The objective of the statute was to facilitate the parents' ability to obtain a judgment on the merits of their federal claims in a federal court. Those lacking experience with the backwaters of federal courts doctrine might be puzzled that another Act of Congress could be necessary to achieve that end. Over the years, however, the federal judiciary has devised a range of tools for avoiding the merits of a claim. Some of these tools might be traced to statutory text; others cannot be. In any event, reluctance to adjudicate can be found in cases involving controversial constitutional questions, ${ }^{11}$ previously litigated issues, ${ }^{12}$ and past or pending state judicial proceedings. ${ }^{13}$ The Schiavo controversy fit all three categories. There had been extensive prior litigation. ${ }^{14}$ Those battles culminated in a state court order directing

$\$ 8$, and declared a "Sense of Congress" that it "should consider" policies for a broader class of incapacitated people, id $\$ 9$.

7. Id. $\$ 1$ (addressing federal claims "relating to the withholding or withdrawal of food, fluids, or medical treatment necessary to sustain [Schiavo's] life").

8. See 28 U.S.C. $\$ 1331$ (2000); see also id. \$1343(a)(3)-(4).

9. $\$ 3,119$ Stat. 15 (emphasis added).

10. See, e.g., 28 U.S.C. \& 2201(a) (authorizing declaratory judgments); Swann v. Charlotte-Mecklenburg Bd. of Educ., 402 U.S. 1, 15-16 (1971) (discussing equitable remedies). But cf. 42 U.S.C. $\$ 1983$ (limiting injunctive relief against judges). (1995).

11. See, e.g., United States v. Nat'l Treasury Employees Union, 513 U.S. 454, 478

12. See generally JaCK H. Friedenthal, MARY Kay Kane \& ARThur R. MILLER, CIVIL PROCEDURE 695-733 (4th ed. 2005).

13. See generally ERWIN CHEMERINSKY, FEDERAL JURISDICTION chs. 12-14 (4th ed. 2003). 2001).

14. See, e.g., In re Guardianship of Schiavo, 780 So. $2 \mathrm{~d} 176$ (Fla. Dist. Ct. App. 
removal of the feeding tube, ${ }^{15}$ and the U.S. Supreme Court had just refused to stay the judgment. ${ }^{16}$ Moreover, Schiavo's parents were surely going to assert federal constitutional claims to keep her alive, arguments that were the subject of media focus and interest-group action. ${ }^{17}$ Without the Act, Schiavo's parents faced numerous objections with exotic-sounding labels like the Rooker-Feldman doctrine, the Anti-Injunction Act, abstention, preclusion, prudential standing principles, and expiration of the applicable statute of limitations.

The Act was written to clear away those sorts of hurdles to a judgment on the merits. ${ }^{18}$ The gist of the legislative effort is in the following sentence:

In such a suit, the District Court shall determine de novo any claim of a violation of any [federal] right of Theresa Marie Schiavo..., notwithstanding any prior State court determination and regardless of whether such a claim has previously been raised, considered, or decided in State court proceedings. ${ }^{19}$

Congress granted Schiavo's parents no more than a referral to federal court for more process.

\section{WHAT THE COURTS DELIVERED}

Yet the Act made little difference. The courts quickly identified a rationale for dismissing the parents' suit without an extended examination of the merits, without contradicting the text of the Act, and without declaring the Act invalid. The mechanism was denial of interim relief necessary to keep Schiavo, and the controversy, alive. ${ }^{20}$

15. See In re Guardianship of Schiavo, No. 90-2908-GD-003, 2005 WL 459634, at *2 (Fla. Cir. Ct. Feb. 25, 2005).

16. See Schindler v. Schiavo, 125 S. Ct. 1622, 1622 (2005).

17. See, e.g., Vickie Chachere, Schiavo's Parents Appeal Judge's Ruling, AP, Mar. 22,2005

18. See $\S 1,119$ Stat. 15 (conferring subject-matter jurisdiction over certain federal claims in the United States District Court for the Middle District of Florida, thus averting a Rooker-Feldman problem); id. $\$ 2$ (purporting to grant standing to "[a]ny parent of" Schiavo, to identify proper defendants, and to direct the district court to adjudicate a suit under the Act regardless of prior consideration in state court, abstention in favor of state judicial proceedings, or exhaustion of state judicial remedies); id. $\$ 4$ (authorizing suit within 30 days of enactment and regardless of any other time limitation).

19. Id. \& 2.

20. See Schiavo ex rel. Schindler v. Schiavo, 403 F.3d 1223, 1225, 1229 (11th Cir. 2005) (affirming the denial of the parents' request for a temporary restraining order to move Schiavo to a hospital and reinsert the feeding tube, based on a poor likelihood of success on the merits). 
In retrospect, judicial resistance can be accounted forespecially for those who see federal courts as a collection of political actors operating with special uniforms but without special constraints on personal preferences. The dispute was controversial to put it mildly, and it appeared that the general public reacted unfavorably to Washington's intervention. Although the purpose of the Act could have been constructed in a manner conducive to interim relief, the plain text spoke to several other procedural hurdles without mentioning that one. ${ }^{21}$ Moreover, the parents' federal claims seemed weak. The statutes they cited looked unhelpful; ${ }^{2}$ their procedural due process claim ran up against seven years of litigation; and their substantive due process count was novel. There was little or no precedent for a standalone federal constitutional right to receive food or medical treatment. In any event, federal courts have a (part-time) tradition of hesitation in controversial cases. ${ }^{23}$ Congress must legislate against this backdrop.

At the same time, there was something bold about mootingby-death a national controversy, particularly one that Congress wanted litigated to some extent. ${ }^{24}$ Congress should have considerable control over federal jurisdiction. Lower federal courts were not mandated by the text of the Constitution; they were authorized at the option of Congress. The federal judiciary itself relies on statutory grants to justify its authority to adjudicate, and federal courts will ordinarily accept legislative adjustments to jurisdiction. Some subservience to legislative wishes makes good sense in democracies with unelected judges, especially if those judges exercise constitutional judicial review. Political control over jurisdiction has its dangers, but it can reduce tension between judicial independence and government accountability to popular will. A system in which courts both control their own

21. The Act was silent on the district court's authority or duty to provide relief before reaching the merits. Prior proposals were not. See S. 653, \& 5, 109th Cong., 1st Sess. (passed the Senate Mar. 17, 2005) (stating that the district court "may issue a stay" of any relevant state court order); see also Schiavo, 403 F.3d at 1227-28 (reprinting a Senate colloquy).

22. See Schiavo ex rel. Schindler v. Schiavo, 357 F. Supp. 2d 1378, 1387-88 (M.D. Fla. 2005) (rejecting claims under the Religious Land Use and Institutionalized Persons Act); Schiavo ex rel. Schindler v. Schiavo, 358 F. Supp. 2d 1161, 1164-66 (M.D. Fla. 2005) (rejecting claims under the Americans with Disabilities Act and the Rehabilitation Act).

23. Compare Bush v. Gore, 531 U.S. 98, 109 (2000) (per curiam), with Elk Grove Unified Sch. Dist. v. Newdow, 542 U.S. 1 (2004), Naim v. Naim, 350 U.S. 891 (1955), and AlEXANDER M. BICKEL, THE LEAST DANGERous BRANCH: THE SUPREME CoURT AT THE BAR OF POLITICS 69-71, 112-13 (1962).

24. Stays of execution are routine where necessary to reach the merits of a first federal habeas application. See Lonchar v. Thomas, 517 U.S. 314, 320 (1996). 
jurisdiction and claim final authority on matters of fundamental law might not be stable and it might not be normatively defensible.

\section{UNDUE PROCESS?}

Was court resistance justified by something more than selfish institutional prerogative? Was the Schiavo Act merely controversial or also unconstitutional? These questions turn out to be difficult. But the constitutional issues involved are connected to a big question about excessive process in constitutional law.

\section{A. CONSTITUTIONAL OBjECTIONS}

The most plausible constitutional challenge to the Act depends on three interrelated arguments under one general idea. The general notion is about institutional roles-in short, that Congress behaved more like a court of appeals than a legislature. The Act did not "adjudicate" the Schiavo case in a strict sense. But Congress did single out one private dispute for additional review in a lower federal tribunal. Three specific arguments fill out this criticism, charging Congress with (1) furnishing special rules of decision for a particular case, (2) while burdening Schiavo's freedom to refuse medical care, and (3) reopening the final judgment of a state court after years of litigation.

\section{Singling Out}

When a legislature singles out one case, especially a case pending in court, it begins to take on the function of adjudicator. In crude terms, legislatures are designed to create prospective and generally applicable law which is interpreted and applied to specific cases by courts. Distinct roles track distinct institutional features, with legislatures composed of representatives accountable to popular (or at least external) will, while courts are somewhat insulated from ordinary politics and built to resolve discrete disputes.

These themes are reflected in case law. For instance, federal courts will defend their freedom to interpret and apply existing law in particular cases. ${ }^{25}$ As well, Article I, Section 9's bill of at-

25. See United States v. Klein, 80 U.S. (13 Wall.) 128, 145-48 (1871). For helpful analysis of Klein's ambiguities and limits, see DAVID P. CURRIE, THE CONSTITUTION IN THE SUPREME COURT: THE FIRST HUNDRED YEARS, 1789-1888, at 308-11 (1985) 
tainder clause has been used to condemn legislative punishment of specified persons. ${ }^{26}$ And the Supreme Court recently confirmed that singling out one person for unfavorable treatment may violate the equal protection clause. ${ }^{27}$ It is at least possible, then, that the Act should have been judicially nullified. Congress intervened in one dispute, legislated new judicial proceedings for three potential plaintiffs and associated defendants, and constrained the shape of the controversy by eliminating defenses and requiring de novo review regardless of prior proceedings. Schiavo's death ended the practical life of the Act.

But generalized separation-of-powers arguments are weakened here, and not only because they have difficulty producing uncontested conclusions in most cases. The United States Government does not have and probably never has had pure institutional forms. Courts generate doctrine to elaborate other positive law, for example, and Congress has enacted private bills from its very beginning. The first private bill was signed by George Washington, and the tradition of personalized redress in immigration and government-claims cases is still alive. ${ }^{28}$ The bar on bills of attainder is limited to punitive legislative measures. ${ }^{29}$ It is no threat to conventional private bills. ${ }^{30}$ And a prohibition more obviously applicable to the Schiavo Act-a restriction on

(pointing out that legislation commonly prescribes rules of decision for the judiciary), and MARTIN H. ReDISH, FEDERAL JURISDICTION: TENSIONS IN THE Allocation OF JUDICIAL POWER 48-49 (2d ed. 1990) (suggesting that the case limits Congress's authority to direct federal courts to apply an independently unconstitutional rule). The subtleties were missing from Judge Birch's concurring opinion on denial of rehearing en banc, which raged against Congress dictating to the courts any "rule of decision" or "standard of review." Thankfully the argument retreated from that broad proposition and turned to the Act's single-case scope. See Schiavo ex rel. Schindler v. Schiavo, 404 F.3d 1270, 1274 75 \& n.5 (11th Cir. 2005).

26. See, e.g., U.S. CoNST. art. I, \$ 9, cl. 3; United States v. Lovett, 328 U.S. 303, 305, 311-18 (1946) (rejecting a legislative attempt to stop paying salaries to three government employees after a House subcommittee found that they had engaged in "subversive activities").

27. See Village of Willowbrook v. Olech, 528 U.S. 562, 564-65 (2000) (per curiam) (focusing on allegations of intentionally different treatment plus irrationality and arbitrariness in a dispute involving a couple's attempt to get connected to the municipal water supply).

28. See, e.g., An Act for the Relief of Richard W. Schaffert, H.R. 1023, 106th Cong., $2 d$ Sess. (passed as amended by the Senate Dec. 14, 2000); 3 DONALD C. BACON, ROGER H. DAVIDSON \& MORTON KELLER, ENCYCLOPEDIA OF THE UNITED STATES CONGRESs 1626-27 (1995); Note, Private Bills in Congress, 79 HARV. L. REV. 1684, 1693-1701 (1966).

29. See Nixon v. Administrator of Gen. Servs., 433 U.S. 425, 472 (1977) (refusing to condemn legislation "merely because [it] imposes burdensome consequences").

30. See Paramino Lumber Co. v. Marshall, 309 U.S. 370, 380 (1940). 
"special legislation" included in some state constitutions ${ }^{31}$-is absent from the federal document. In addition, the Supreme Court has held that a statutory "class of one" will not always violate the Constitution. ${ }^{32}$ Congress's selective treatment of the Schiavo controversy cannot, standing alone, establish the Act's invalidity. The Act might have been a permissibly narrow and remedial intervention in a hard-luck case, consistent with part of the private bill tradition, and despite the husband's opposition to more process. ${ }^{33}$

\section{Burdening Liberty}

Criticism of the Act can be strengthened if an individual liberty interest was jeopardized, which might distinguish much of the history of private bills. The husband's position was that Schiavo would not want to remain indefinitely attached to a feeding tube while "living" in a persistent vegetative state. And the Supreme Court has suggested that Fourteenth Amendment liberty reaches a person's choice to refuse artificially delivered nutrition and water. ${ }^{34}$ One might worry that the Act unconstitutionally burdened Schiavo's liberty to refuse treatment by adding a new avenue for judicial assessment of her situation, at the behest of those who were obviously opposed to the discontinuation of care. Although concern for "right-to-die" choices does not depend on Congress targeting one case, a one-case-only burden might be even more difficult to defend.

But describing this criticism destroys its force. The argument turns on Schiavo's preferences before her injury (or her simulated post-injury preferences), which involves a factual allegation that her parents rejected. At the very least, they believed their daughter was more mentally functional than others supposed and that she would want (or actually did want) to continue living. To be sure, the Florida state courts disagreed. A trial

31. See, e.g., ILL. CONST. art. 4, \& 13; MINN. CoNST. art. 12, \&1.

32. See, e.g., Nixon, 433 U.S. at 472; Maine Central R.R. Co. v. Brotherhood of Maintenance of Way Employees, 813 F.2d 484 (1st Cir. 1987), cert. denied, 484 U.S. 825 (1987); accord Railway Labor Executives' Ass'n v. Gibbons, 455 U.S. 457, 468 (1982) (distinguishing the bankruptcy clause's uniformity requirement); see also U.S. CONST. art. I, \$ 8, cl. 4 \& art. IV, \& 1 .

33. Cf. Paramino Lumber, 309 U.S. at 375-78 (permitting a special legislative extension of time to challenge a refusal to award compensation from an employer to an employee).

34. See Cruzan v. Dir., Mo. Dep't of Health, 497 U.S. 261, 278-79 (1990); see also Sell v. United States, 539 U.S. 166, 178 (2003) (discussing prisoners' interest in preventing administration of antipsychotic drugs). 
court earlier found, by clear and convincing evidence, that Schiavo would have preferred to die in these circumstances. Relying on prior judicial proceedings, however, presents a new issue. Schiavo's personal liberty interest in deciding the course and extent of her care was not jeopardized by legislation extending judicial process over federal claims, unless her opposition to additional care was a given - and it was not.

Indeed, her parents ultimately claimed that Schiavo had a constitutional right to continue artificial feeding. ${ }^{36}$ This claim was premised on their belief that Schiavo would want (or, again, actually did want) continued care. Had that belief been factually accurate, more process would have advanced rather than hindered the asserted liberty. ${ }^{37}$ The "procedural due process" claim was equally secure. According to the parents, the state courts provided inadequate or biased proceedings in reaching a conclusion about their daughter's wishes. ${ }^{38}$ We can safely assume that a life or liberty interest was at stake in the state litigation, and deficient process can be a constitutional violation even if the state reaches an accurate conclusion. ${ }^{39}$ At least nominal damages would then be available for the due process violation. True, substantial compensatory damages sound inappropriate insofar as Schiavo lacked consciousness during the allegedly flawed proceedings. And it would have made little sense to nullify the state court order if it represented the legally correct decision based on accurate factual findings. But to repeat, the parents did not accept those findings and, thus far, we have not identified a constitutional barrier to their obstinacy.

\section{Unsettling Judgments}

If the above is correct, then the Act's constitutionality probably rests on the significance of prior judicial proceedings.

35. See In re Guardianship of Schiavo, No. 90-2908GD-003, at 9 (Fla. Cir. Ct. Feb. $11,2000)$.

36. See Schiavo ex rel. Schindler v. Schiavo, 358 F. Supp. 2d 1161, 1167 (M.D. Fla. 2005) ("Plaintiffs allege that 'depriving [Schiavo] of nutrition and hydration contrary to her wish to live is a violation of her Fourteenth Amendment right to life."'). The parents also raised Eighth Amendment and equal protection claims. See id.

37. This seems true for the parents' free exercise of religion claim as well as their substantive due process claim. See Schiavo, 358 F. Supp. 2d at 1167-68; Schiavo ex rel. Schindler v. Schiavo, 357 F. Supp. 2d 1378, 1387-88 (M.D. Fla. 2005).

38. See Schiavo, 357 F. Supp. 2d at 1384-87; see also Schiavo, 358 F. Supp. 2d at 1166-67 (describing the parents' argument that decisions to stop hydration and nutrition require clear and convincing evidence that the incapacitated person would have made that decision).

39. See Carey v. Piphus, 435 U.S. 247, 266 (1978). 
Precisely targeted legislation is not necessarily invalid; and identifying an intolerable burden on Schiavo's liberty depends on acceptance of state court conclusions about her preferences. Without determining the significance of past process, no federal court could know whether Schiavo's (imputed) choice was being subjected to outrageously atypical procedural burdens-or instead safeguarded by thankfully extraordinary legislative concern. But if state judicial conclusions deserve respect, then the Act is in trouble. Congress would be telling the husband, "Double or nothing," without the "double."

Constitutional text does not answer this objection but case law provides some support. The full faith and credit clause in Article IV dictates respect for State A's judgments in State B's courts, while saying nothing about federal courts and providing Congress authority over the effect of a prior state proceeding. Still, the Supreme Court recognizes the importance of finality in court judgments, if the proposed basis for reopening was not established beforehand. Plaut v. Spendthrift Farm, Inc. ${ }^{40}$ is the key case. It invalidated a federal statute insofar as it required federal courts to reopen final federal judgments in civil lawsuits. Concluding that the statute violated separation-of-powers principles, the majority opinion emphasized the judicial function of actually deciding cases, along with founding era examples of state legislatures granting new trials or otherwise interfering with the adjudication of particular cases. ${ }^{41}$ The Schiavo Act was similar. ${ }^{42}$

Yet Plaut's holding does not settle the matter. First of all, the Schiavo controversy involved state rather than federal court judgments. The Plaut opinion reserved due-process-based arguments as a way of limiting its holding, and its rule might stop short of insulating state judgments from federal statutes. ${ }^{43}$ The opinion also distinguished judgments of territorial courts and administrative agencies, ${ }^{44}$ which might suggest a category of non-

40. 514 U.S. 211 (1995).

41. See id at 218-19, 221-23.

42. Justice Breyer would have limited Plaut's holding to legislation targeting a small class of cases. See id. at 240-41 (concurring opinion); accord INS v. Chadha, 462 U.S. 919, 966-67 (1983) (Powell, J., concurring). Such targeting, which Justice Breyer used to more tightly analogize the federal statute to the typical judicial function, is obviously present in the Schiavo Act, and not necessary for a constitutional violation in the eyes of the Plaut majority.

43. To be precise, the Court said it wished to avoid calling into question state legislation, see Plaut, 514 U.S. at 226-27, 234, which indicates even less about state court judgments.

44. See id. at 232. 
Article III tribunals deserving less constitutional respect. ${ }^{45}$ Furthermore, a New Deal era decision upheld federal price control legislation that prevented eviction pursuant to state court judgments. ${ }^{46}$

It might be hard to believe that Plaut would have come out the other way had the litigation been concluded in a state court. Federalism arguments aside, an originalist might recall that Congress need not have established lower federal courts at all, and then wonder why it ought to have greater authority to reopen state court judgments in a hypothetical system dependant on their trial-level jurisdiction. If such reopening was forbidden in 1789 , in line with common criticism of state legislatures acting as appellate tribunals, then a contrary result seems difficult to support with subsequent developments. State courts might be more likely to err when adjudicating federal claims than are federal courts; but that assertion is contested ${ }^{47}$ and hardly accepted in contemporary Supreme Court decisions. ${ }^{48}$

A state/federal distinction is not the only potentially relevant boundary, however. Outstanding injunctions have been treated differently from judgments in damages actions. In Miller v. French, ${ }^{49}$ the Court distinguished Plaut while evaluating a federal statute that required reconsideration of prison-reform injunctions. ${ }^{50}$ The state trial court's order in the Schiavo case could be treated similarly. ${ }^{51}$ At the same time, Miller might distinguish itself. The opinion relies on a congressional decision to change the underlying rule of decision. ${ }^{52}$ But the Schiavo Act emphatically does not alter the law under which the parents' claims would have been assessed. Substantive law was untouched. We

45. Cf. Martin v. Hunter's Lessee, 14 U.S. (1 Wheat.) 304 (1816) (upholding appellate jurisdiction over state court decisions); Printz v. United States, 521 U.S. 898, 928-29 (1997) (cabining the federal government's authority to direct the actions of state officers, but distinguishing state courts); New York v. United States, 505 U.S. 144, 178-79 (1992) (same).

46. See Fleming v. Rhodes, 331 U.S. 100, 102, 106-07 (1947) (rejecting a vested rights argument assertedly grounded in due process, but focusing on retroactivity).

47. See Martin H. Redish \& Suzanna SherRy, Federal Courts: Cases, COMMENTS AND QUESTIONS 271-75 (5th ed. 2002) (surveying the parity debate).

48. See, e.g., Tafflin v. Levitt, 493 U.S. 455, 458 (1990); Stone v. Powell, 428 U.S. 465, 493-94 n.35 (1976).

49. 530 U.S. $327(2000)$.

50. See id. at $342-45$.

51. See supra note 2.

52. See Miller, 530 U.S. at 342 . The idea seems to be that if Congress changes substantive law, it is not directing courts to interpret and apply existing law as the legislature prefers. 
can therefore surmise, but cannot know, how the Supreme Court would judge the Act.

Narrowly stated and with attention to precedent, the constitutional issue devolves into something like this: whether Congress has authority to require federal courts to adjudicate federal claims without regard to a prior state court judgment awarding injunctive relief, where the federal statute does not alter the substantive rules of decision (although it does eliminate certain defenses) and where one controversy is selected for special treatment. But however narrow the question, the best answer is intertwined with the broader problem of excessive process in government decision making.

\section{B. EXCESSIVE PROCESS IN CONSTITUTIONAL LAW}

As a matter of public policy, there is no question that a decision-making process can be excessive. For my purposes, "excessive" simply means too costly on net for private parties, the state, or both. And by "process" I mean conduct that is both (1) authorized by law, including that which may be demanded by private parties, ${ }^{\text {s3 }}$ and (2) for the purpose of reaching any government decision. ${ }^{54}$ Opposition to excessive process is shared by everyone from Ronald Dworkin to Richard Posner to Charles Dickens. $^{55}$ In the same spirit, Mathews v. Eldridge $e^{56}$ famously

53. See, e.g., U.S. CONST. amend. VI (guaranteeing criminal defendants compulsory process to obtain witnesses).

54. Cf. Cochrane v. Deener, 94 U.S. 780, 787-88 (1877) ("A [patentable] process is a mode of treatment of certain materials to produce a given result."). This definition is not tied down by the substance/procedure distinction at stake in the Rules Enabling Act, 28 U.S.C. \& 2072(a)-(b). Examples of "process" include notice requirements, hearings, methods of information collection, decision-maker deliberation, written explanations, and appeals. But for now, it seems best to simplify the analysis by excluding some aspects of "process" most-broadly defined, such as mechanisms for financing decision-making and/or deterring its use-including filing fees and campaign contributions. The same can be said for substantive law governing elements of a claim or defense. Decision costs are affected by selecting rules as opposed to standards (in the law-and-economics sense, see Louis Kaplow, Rules Versus Standards: An Economic Analysis, 42 DUKE L.J. 557, 561 (1992)), but I make no claim about whether the Federal Constitution favors one or the other.

Finally, I express no firm opinion on the degree to which some controversies should not be "decided" with any real finality. (Perhaps much legislative business falls into this category.) I will assume that a meaningful decision can be specified and is desired by all interested parties.

55. See Charles Dickens, Bleak House 13-14 (Oxford Univ. Press, 1996) [1853] (discussing the everlasting suit of Jarndyce v. Jamdyce); RONALD DWORKIN, A MATTER OF PRINCIPLE 77-78, 84, 92 (1985) (denying rights to the most accurate possible procedures); RICHARD A. POSNER, ECONOMIC ANALYSIS OF LAW ch. 21 (6th ed. 2003).

56. 424 U.S. 319 (1976). 
recognized the costs of added process as an "interest" that helps cabin constitutional demands for more process. ${ }^{57}$

It should be easy to see why caps on decision costs are attractive. Whatever praiseworthy objectives a process might achieve-accurate information about existing law and historical fact, just application of law to individual cases, creation of socially beneficial new law, moral legitimacy and peaceful acceptance of government decisions ${ }^{58}$ - those benefits come at a price. Losses from process are counted not only in time or dollars, but also opportunity costs of all kinds plus the burdens of extended uncertainty, delay, and conflict. These costs are widely suffered: by decision-makers, by other participants in the process, and by society. ${ }^{59}$ Our support for extensive decision-making protocols should then vary with circumstances, including the costs of erroneous judgment.

We certainly will disagree about when the costs become excessive. But anybody should be able to cite examples of decisionmaking so protracted or onerous that their tolerance for squabbling or hand wringing runs out. Consider the multi-forum, multi-decade fight over nuclear waste storage at Yucca Mountain in Nevada. ${ }^{60}$ Or the most oppressive discovery demands of the most aggressive litigators. ${ }^{61}$ Or the filibuster of judicial nominees - and perhaps the accompanying debate on the desirability and constitutionality of the filibuster. ${ }^{2}$ Or those lawsuits, agency rulemaking procedures, immigration proceedings, ${ }^{63}$ and even

57. Id. at 335 (listing "the Govermment's interest, including ... the fiscal and administrative burdens that the additional or substitute procedural requirement would entail").

58. See, e.g., E. Allan LIND \& TOM R. TYleR, THE SOCIAL Psychology of PROCEDURAL JUSTICE 66-83 (1988) (connecting perceptions of procedural "fairness" to satisfaction and compliance with outcomes); Jerry L. Mashaw, The Supreme Court's Due Process Calculus for Administrative Adjudication in Mathews v. Eldridge: Three Factors in Search of a Theory of Value, 44 U. CHI. L. REV. 28 (1976) (adding individual dignity and equality as procedural values); Robert E. Scott, Constitutional Regulation of Provisional Remedies: The Cost of Procedural Due Process, 61 VA. L. REV. 807, 810 (1975) (concentrating on accuracy in adjudication); Lawrence B. Solum, Procedural Justice, 78 S. CAL. L. REV. 181 (2004) (emphasizing participation to foster "legitimacy"); $c f$. DWORKIN, supra note 55 , at $72-73,102-03$ (struggling to identify moral harm from inadequate process).

59. See generally POSNER, supra note 55, at 563; Scott, supra note 58, at 810.

60. See Nuclear Energy Inst. v. EPA, 373 F.3d 1251, 1257-62, 1268-73 (D.C. Cir. 2004) (per curiam) (rejecting the agency's 10,000 year compliance period and remanding).

61. Cf. In re Convergent Technologies Sec. Litig., 108 F.R.D. 328, 330, 333, 349 (N.D. Cal. 1985) (refusing to compel immediate answers to about 1,000 interrogatories).

62. But cf. Michael J. Gerhardt, The Constitutionality of the Filibuster, 21 CONST. COMMENT. 445, 446 \& n.4 (2004) (noting little past treatment by legal scholars).

63. See Gaur v. Gonzalez, 124 Fed. Appx. 738, 743 (3d Cir. 2005) (noting that the 
presidential elections that seem to drag on endlessly. Some questions are not worth considering for very long, and perhaps no question deserves to be considered for a lifetime.

The constitutional question is not the same as the policy question, however. The issue we are interested in is whether federal constitutional law does or ought to contain a judicially enforceable norm against "undue process." Even if we could settle on a norm, practical questions of implementation must be resolved. ${ }^{64}$ Federal courts might not be the ideal institution for enforcing the ideal norm. It might be best if their judgment on at least certain aspects of the matter were either irrelevant or respectful of assessments made by others. In this space I cannot provide all of the consideration that these issues deserve, but I can offer a foundation for future work.

\section{Process Floors and Ceilings in Current Law}

If forced to characterize the provisions of the U.S. Constitution as generally imposing either floors or ceilings on process, the choice seems easy. Our constitutional text is bursting with procedure. Obvious examples are the due process clauses of the Fifth and Fourteenth Amendments, as conventionally understood. ${ }^{65}$ These clauses safeguard a wide range of private losses and are not expressly limited to particular government actors. ${ }^{66}$ Other commonly invoked provisions speak to process associated with courts, especially on the criminal side. The Fifth Amendment requires indictment by grand jury in certain cases. The Sixth Amendment imposes on government a duty to inform the criminally accused of the nature of the accusation, guarantees confrontation of adverse witnesses and compulsory process for obtaining other witnesses, and ensures access to counsel. Article III, Section 2, establishes a right to demand trial by jury in cer-

agency initiated proceedings 16 years ago and took 9 years to decide the immigrant's appeal).

64. See, e.g., NEIL K. KOMESAR, IMPERFECT ALTERNATIVES: CHOOSING INSTITUTIONS IN LAW, ECONOMICS, AND PUBLIC POLICY 5 (1994); LAWRENCE G. SAGER, JUSTICE IN PlaINClothes: A THEORY OF AMERICAN CONSTIUUTIONAL PRACTICE 6 (2004); David A. Strauss, The Ubiquity of Prophylactic Rules, 55 U. CHI. L. REV. 190, 208 (1988); Cass R. Sunstein \& Adrian Vermeule, Interpretation and Institutions, 101 MICH. L. REV. 885, 886 (2003).

65. See, e.g., Wilkinson v. Austin, 545 U.S. 209 (2005); Hamdi v. Rumsfeld, 542 U.S. 507 (2004); Mathews v. Eldridge, 424 U.S. 319 (1976); Fuentes v. Shevin, 407 U.S. 67 (1972).

66. Courts tend to balk at supplementing rulemaking processes, however. See Vermont Yankee Nuclear Power Corp. v. Natural Res. Def. Council, 435 U.S. 519, 524 (1978); Bi-Metallic Inv. Co. v. State Bd. of Equalization, 239 U.S. 441, 445 (1915). 
tain criminal proceedings, and the Seventh Amendment does likewise for civil trials. ${ }^{67}$

Process floors are imposed in circumstances beyond adjudication, too. Aside from the Fourth Amendment's warrant requirements, consider the processes for generating positive law. The institutions and procedures involved in legislation and constitutional amendment are almost comically demanding, with bicameralism only the first headache for proponents of change. Madisonian republicanism was intended, in part, to make a virtue of gridlock. Granted, these machinations are not endless. We have two rather than three houses of Congress to approve legislation, and little chance that a third house is permissible without a formal constitutional amendment. ${ }^{68}$ It is nevertheless difficult to extract from the text an overarching commitment to procedural parsimony.

Accordingly, process ceilings are less apparent. The Federal Constitution lacks an explicit, general commitment to limiting the burdens of government decision making. ${ }^{69}$ A careful search exposes only a few places where the document indicates that decisions will be swift or final or otherwise capped as to burden. Criminal defendants - who enjoy guarantees of both minimum and maximum procedure that may increase government lossesare immunized from double jeopardy, cannot be forced to testify against themselves, and must receive a speedy trial under the Fifth and Sixth Amendments. Jury findings of fact may not be re-examined under the Seventh Amendment. And states are obligated to give full faith and credit to each other's judicial proceedings. ${ }^{70}$ But that's about it. No simple, unified, anti-process principle emerges from these provisions. They mix skepticism of big government with respect for community judgment and a general rule for resolving certain inter-state conflicts.

At this date, judicial precedent adds little to the notion of undue process. Courts rarely address complaints from private parties that government has imposed unconstitutionally exces-

67. See also U.S. CoNST. amend. XIII (abolishing slavery except as a postconviction penalty).

68. Contrast the congressional committee structure and (perhaps) filibusters ended only by supermajority vote. See id. art. I, $\$ 5$, cl. 2 (stating that "[e]ach House may determine the Rules of its Proceedings").

69. Cf. GA. CoNST. art. VI, § IX, para. I (the judiciary must provide "speedy, efficient, and inexpensive resolution of disputes and prosecutions"); ILL. CONST. art. I, $\S 12$ (guaranteeing prompt justice). $\S 1$.

70. Congress may dictate the effect of such proceedings. See U.S. CONST. art. IV, 
sive process, and they have vindicated such concerns even less frequently. ${ }^{71}$ There are just a handful of situations in which the judiciary is likely to accept undue process objections.

Most significant, other constitutional values can be threatened by lots of process. One of these values condemns invidious or arbitrary government action. ${ }^{72}$ Courts must see something better than animosity before they will legitimate burdens imposed by the state. An excessive decision-making process could violate this principle. The same goes for more specific constitutional values. No court would permit a legislature to impose heightened evidentiary requirements on free exercise claims or AsianAmerican plaintiffs. ${ }^{3}$ Some actual free speech cases fit this model, too. When government wants to review the content of private expression before licensing its dissemination, courts impose administrative obligations to respond swiftly. ${ }^{74}$ Quick response times might actually increase the cost of a licensing scheme, of course, but these court decisions are still sensitive to the burden on private parties. Likewise in the equal protection field. Courts have occasionally invalidated attempts by one segment of the population to elevate the procedural hurdles that another segment must clear in order to make legal change, such as by entrenching opposition to antidiscrimination laws in state constitutions or city charters. ${ }^{75}$ In any event, the presence of ad-

71. See Tahoe-Sierra Pres. Council, Inc. v. Tahoe Reg'l Planning Agency, 535 U.S. 302 (2002) (denying that a temporary development moratorium, to formulate a land use plan, was a per se taking); Lackey v. Texas, 514 U.S. 1045 (1995) (denying certiorari in a case involving an inmate's claim that his long incarceration on death row would render his execution cruel and unusual); Isaacs v. Bowen, 865 F.2d 468, 475-77 (2d Cir. 1989) (rejecting an excessive process claim involving hearings in Medicare appeals); Angstman v. City of Boise, 128 Idaho 575, 578, 917 P.2d 409, 412 (Idaho Ct. App. 1996) (same in the zoning context); Mata v. Montoya, 91 N.M. 20, 21, 569 P.2d 946, 947 (N.M. 1978) (rejecting what appears to be a non-constitutional objection in an employment dispute). But cf. Cleveland Bd. of Educ. v. Loudermill, 470 U.S. 532, 547 (1985) ("At some point, a delay in the post-termination hearing would become a constitutional violation."); Barry v. Barchi, 443 U.S. 55, 66 (1979) (condemning delayed hearing without reason in a government employment dispute); Kelly v. Railroad Retirement Bd., 625 F.2d 486, 490 (3d Cir. 1980) (holding that a nearly four-year delay in processing a disability-based benefits claim violated due process despite the agency's plea of inadequate resources); Sayles Hydro Assocs. v. Maughan, 985 F.2d 451, 454-54 (9th Cir. 1993) (holding that a preemption claim was ripe: "[t]he hardship is the process itself").

72. See, e.g., Romer v. Evans, 517 U.S. 620 (1996)

73. Setting aside the possibility that "strict scrutiny" might be satisfied.

74. See, e.g., Freedman v. Maryland, 380 U.S. 51 (1965).

75. See Hunter v. Erickson, 393 U.S. 385 (1969); Reitman v. Mulkey, 387 U.S. 369 (1967); see also Romer, 517 U.S. at 631; Citizens for Equal Prot., Inc. v. Bruning, 368 F. Supp. 2d 980 (D. Neb. 2005) (striking down Nebraska's attempt to constitutionalize its opposition to gay marriage, without finding a federal constitutional obligation to recognize it). 
ditional process is not doing much work here. Process is merely one type of burden made troubling by the impact on independently valued conduct or parties.

A smattering of other precedent intimates special concern for excessive process. No theme is immediately apparent in these cases and their significance is limited. But there is one standout. There is significant judicial sensitivity to delay-at least when the decisions of other institutions are under challenge, the private need seems acute, and the justification for inaction underwhelms the courts. Thus, in the context of discretionary government benefits claims, delay is a recognized constitutional problem. ${ }^{76}$ Note also that land developers have had some success using state constitutional law against municipalities trying to slow the pace of change. ${ }^{n}$ Delay is obviously not a recently discovered element of decision costs. Impatience for government responses to citizen complaints was present in the Magna Carta, and our courts sometimes declare that "justice delayed is justice denied." 79

Another example was discussed above: the rule against legislation that retroactively reopens non-injunctive final federal judgments. But the rule is narrow. Nothing about it prohibits Congress from multiplying the grounds for reopening judgments if the legislation applies only prospectively. ${ }^{80}$ Due process cases contribute little else. One aspect of the minimum-contacts test

76. See supra note 71 (collecting cases).

77. See Mitchell v. Kemp, 176 A.D.2d 859, 575 N.Y.S.2d 337 (N.Y. Sup. Ct. App. Div. 1991) (invoking arbitrariness against a land-use moratorium and a delayed zoning ordinance).

78. See Magna Carta 940 (1215) ("To no one will we ... delay right or justice."), reprinted in SOURCES OF OUR LIBERTIES: DOCUMENTARY ORIGINS OF INDIVID. UAL LIBERTIES IN THE UNITED STATES CONSTITUTION AND BILL OF RIGHTS 1, 17 (Richard L. Perry ed., 1959).

79. E.g., Jones v. Clinton, 72 F.3d 1354, 1363 (8th Cir. 1996) (Beam, J., concurring), aff'd, Clinton v. Jones, 520 U.S. 681 (1997); LAURENCE J. PETER, PETER'S QuOTATIONS 276 (1977) (attributed to William Gladstone). The concept of delay helps illuminate a distinction between objections to excessive decision costs (broadly understood) and "too much process." Delay can generate decision costs that fall on interested parties. But an objection to delay will not necessarily isolate a feature of the decision-making process for elimination. The objection could simply be that a hearing take place sooner rather than later. Likewise, the best remedy for delay might not be "less process" but rather more resources to handle the workload. I use terms like "excessive process" loosely. I mean to capture the idea of decision costs, including the burden that results when government decision-makers act at a leisurely pace.

80. The Plaut Court did suggest that the federal judiciary might be free to raise preclusion arguments sua sponte. See Plaut v. Spendthrift Farm, Inc., 514 U.S. 211, 232 \& n.6 (1995). But even if this is a constitutionally protected prerogative, Congress may control the effect of state judgments in other state courts and may legislate preclusion rules for other contexts and for federal judgments. See, e.g., 28 U.S.C. \$1738. 
for personal jurisdiction recognizes the burden imposed on defendants by an inconvenient forum. ${ }^{81}$ More tangentially, consider state sovereign immunity. States may consent to suit by private parties for damages, but otherwise they are usually immune. ${ }^{82}$ These rules have an anti-process character in that states may opt out of litigation without escaping formal legal obligations. Yet like minimum-contacts analysis, sovereign immunity doctrine does not entirely shield states from process burdens. The issue is how, not whether, legal duties will be enforced. Finally, the canon for evaluating whether government has offered enough process identifies a competing government interest in cost control. ${ }^{83}$ But this is an interest, not necessarily a constitutional concern. For that, we need to think generally about the virtues of an excessive process norm.

\section{Excessive Process in Theory}

Little existing law supports any wide-ranging constitutional norm against excessive process. Insufficient process is a far more prevalent force. Is this normatively desirable? We can think about this question from at least two perspectives: rights theory and structural or institutional logic. Neither provides much support for a judicially enforceable undue process claim.

\section{a. Fundamental rights}

If judicially enforced constitutional law should focus on a set of fundamental human rights, it will be difficult to make room for excessive process objections. ${ }^{84}$ This model sits on a contentious normative claim about the character of constitutional law, whatever its descriptive power, and a rights theory can be specified in many ways. But hopefully we can avoid taking posi-

81. See World-Wide Volkswagen Corp. v. Woodson, 444 U.S. 286, 292 (1980); Kevin C. McMunigal, Desen, Utility, and Minimum Contacts: Toward a Mixed Theory of Personal Jurisdiction, 108 YALE L.J. 189, 233-34 (1998).

82. See Alden v. Maine, 527 U.S. 706, 755-77 (1999) (noting consent and other limits); see also Nevada Dep't of Human Res. v. Hibbs, 538 U.S. 721, 724-29 (2003). Constitutionally inspired respect for the states might also help explain some court-fashioned restrictions on habeas corpus. See Teague v. Lane, 489 U.S. 288, 308 (1989); Stone v. Powell, 428 U.S. 465 (1976). But these results might be too derivative-a criminal-justicerelated subset of a federalism subset of the general undue process problem. Moreover, these cases have generated enough procedural rules of their own to forestall any snap judgment that they reduce decision costs.

83. See Mathews v. Eldridge, 424 U.S. 319, 335 (1976).

84. Cf. DWORKIN, supra note 55, at 96 (remarking that "neither party has any right against procedures more accurate than the accuracy required by" Dworkin's basic procedural right, which he defines in terms of consistency in weighting risks of moral harm from substantive rights violations rather than a set level of accuracy). 
tions on those matters. Assuming any such rights theory applies, undue process seems like a poor fit.

Recall that an undue process objection is founded on costs associated with decision-making: money, time, other resources, uncertainty. But these costs are ubiquitous and, partly for that reason, ordinary. By contrast, due process claims might be more easily and more often affiliated with human values typically denominated fundamental, like individual dignity and equal or personalized treatment. Providing a hearing in which a person or her advocate may explain her position might be a dignitary interest of constitutional dimension. ${ }^{85}$ And even if it isn't, such participation rights can enhance accuracy in the adjudication of substantive rights. Preventing someone from enjoying such participation, for the purpose of saving cash or avoiding hassle, cannot reach the same order of importance in a fundamental rights theory. This seems especially true insofar as costs are shouldered by government officials and anonymous taxpayers. Otherwise, every fundamental human right could develop an anti-right pushing in the opposite direction and the very notion of fundamentality loses meaning.

To be sure, a theory of rights need not-and cannot, in any practical sense-encompass claims to maximum accuracy in the adjudication of rights regardless of cost. But at least the motivation for enhanced decision-making procedures is tightly connected to arguably imperative concerns. ${ }^{86}$ Not so for excessive process concerns, or at least not necessarily so. We might imagine added process that also implicates concerns like dignity and equal respect. Requiring only the poor to personally participate in hearings involving their debts would not only impose ordinary costs on that class; it might also carry an intolerable suggestion of untrustworthiness. Yet this is simply a replay of the rationale for derivative excess process claims: an independent commitment with a high (lexical) priority is threatened by more process, yet only coincidently. ${ }^{87}$ The essential problem is humiliation, or disregard, or some other value. Process is only a vehicle for the injury. Even if the same doubts can be raised about rights to ample process - that such rights must piggyback on our dedication

85. See Fuentes v. Shevin, 407 U.S. 67, 80-81 (1972) (referring to both fair play and mistaken deprivations); id at n.22 (downgrading "rather ordinary costs" of process compared to a right to process before a "property" deprivation takes place); Mashaw, supra note 58 , at 49 .

86. See generally DwORKIN, supra note 55, at 76-78.

87. See supra text accompanying notes $72-75$. 
to other human values - this shared weakness cannot help the argument for rights against excessive process.

Nothing seems to change if we concede that there is a right to defeat unfounded claims of right. ${ }^{88}$ The concession indicates additive rights to adequate process in the service of accuracy and other procedural values. It need not produce rights in one party to minimize the procedures demanded by another party.

\section{b. Institutional choice and design}

The cost-based objections propelling the idea of undue process rest more easily within structural arguments and institutional theory. A primary task for such analysis is to choose and design institutions that are most likely to achieve given objectives. ${ }^{89}$ Costs of all sorts may be considered. Now, some might confine these arguments to pure policy and deny their relevance to constitutional law. This is not a reason to stop now, though. As with rights theories, so too for institutional theories: we need not concede decisive power to any one of them. If they all suggest the same answer, we might reach a satisfying conclusion without deeper commitments. ${ }^{90}$

The critical question is what good would be done by judicially cognizable undue process claims. There is no doubt that undesirable costs are associated with government decisionmaking, and that officials will sometimes err by adding too much process. Indeed, high-cost decisional process might be a way for officials to build turf. ${ }^{91}$ Let us assume, moreover, that excessive process is a constitutional violation at least sometimes. The proposal at issue is more pointed, however. It contemplates judicial intervention and, if conventional practices apply, judicial supremacy on the matter. Is this desirable?

A quick answer is not possible, in part because courts might police any number of institutions in countless circumstances and because there is no simple and consensus model of official be-

88. See generally DWORKIN, supra note 55, at 96 ("When issues of substance are at stake, the defendant's rights begin where the plaintiff's leave off.").

89. See, e.g., David L. Weimer, Institutional Design: An Overview, in INSTITUTIONAL DESIGN 1, 12 (David L. Weimer ed., 1995) (noting a dialogical strand as well); Elizabeth Garrett \& Adrian Vermeule, Institutional Design of a Thayerian Congress, 50 DUKE L.J. 1277, 1280 (2001) (distinguishing institutional choice from institutional design).

90. See Cass R. Sunstein, ONE CASE at a Time: Judiclal Minimalism ON THE SUPREME COURT 249-50 (1999) (discussing incompletely theorized agreements).

91. But cf. Daryl J. Levinson, Empire-Building Government in Constitutional Law, 118 HARV. L. REV. 915 (2005) (challenging assumptions that government tends to unjustifiably expand in any systematic way). 
havior. ${ }^{92}$ Progress nevertheless can be made with an important doubt: it is far from clear that leaving the issue to ordinary law and politics will result in serious and systematic errors.

Without undue process claims, the system would function much the way it does now. ${ }^{93}$ Congress might legislate to add, subtract, or otherwise modify the decision-making procedures for the executive branch and for the federal judiciary. Insofar as it has not, the executive and the judiciary might draft their own rules for their own purposes, as well as consider pleas for reform. ${ }^{95}$ If the system errs and manufactures excessive protocols for decision, pressure for change may come from either officers within each of those institutions or from interested outsiders. And the mechanism for reform could be either internal (the executive or the judiciary altering their own process) or external (legislation or even constitutional amendment).

Constitutional judicial review is an addition of questionable value. The resulting anti-procedure norms would be judicially approved if not wholly designed, and difficult to modify. Power over process might be unjustifiably skewed toward court preferences, not only within the judiciary but elsewhere. We might worry that officials will habitually over-economize on process to save themselves the hassle; constitutional text suggests as much. But that kind of distrust tends to distinguish due process from undue process claims, and it does not confront the downside of judicial review.

A court-centered approach is not all bad but it isn't a convincing improvement, either. Consider a few generalizations about official behavior. One is that familiarity builds practical

92. See, e.g., Nancy Maveety, The Study of Judicial Behavior and the Discipline of Political Science, in THE PIONEERS OF JUDICIAL BEHAVIOR 1, 4-5, 33-35 (2003). tices.

93. The analysis here brackets Congress's internal procedures as well as state prac-

94. See U.S. CONST. art. I, $\$ 8$, cl. 18 (granting Congress power "[t]o make all Laws which shall be necessary and proper for carrying into Execution ... all other Powers vested by this Constitution in the Government of the United States, or in any Department ... thereof").

95. See, e.g., 28 U.S.C. $\$ 2071$ (a) (2000) (granting federal courts authority to "prescribe rules for the conduct of their business," if consistent with statutes); $c f$. Department of the Navy v. Egan, 484 U.S. 518, 527 (1988) (recognizing inherent executive authority to restrict access to sensitive information).

96. Nor is it apparent that pro-process interest groups will routinely dominate antiprocess interests. Certainly rule changes in civil procedure and habeas corpus include important efforts to streamline decision-making. Cf. Freedom of Information Act, 5 U.S.C. § 552(a)(6) (2000) (setting response times); Tax Injunction Act, 28 U.S.C. § 1341 (2000) (restricting district court injunctions if "a plain, speedy and efficient remedy may be had in the courts of such State"). 
knowledge. Those who repeatedly perform similar tasks in similar settings have an advantage in evaluating the consequences of one process over another. A second idea is that self-judgment can threaten the public good. Like anyone else, government officials can be selfish and irresponsible or myopic and overconfident about their own ability to perform familiar duties. Outsiders might offer a more reliable assessment of work performed by others. To a certain extent these two ideas present an unhappy trade-off: competence for bias, dispassion for naiveté. Courts are subject to these complications. They might be honest yet mistaken brokers, or interested yet expert players. These risks might be at their apex when courts are asked to evaluate the net costs of a decision-making method and where judges might enjoy important benefits from its absence.

Equally important are the alternatives to constitutional law. Even if federal courts are reliable here-after all, they deal in process constantly and their partial insulation from daily politics can be advantageous - the objective might be achieved subconstitutionally. Formal amendments to statutes and rules are not the only alternatives. Any marginally creative method of statutory interpretation will provide opportunities to assess the consequences of first-class process, not to mention the possibility of common-law claims for abuse of process and the like. ${ }^{\text {.7 }}$ All of this can be done without the judiciary freezing the results with fundamental law.

Finally, an undue process claim needs limitations which are not easy to see. Government decision-making always imposes costs. And familiar procedures might be left in doubt as the judiciary works out the boundaries of excessive process objections. Attractive targets include federal habeas corpus, the discovery system for civil litigation, as well as an almost endless range of administrative procedure. It would be a miracle if all of these targets already operate with an optimal degree and form of process. This is a lot to put up for grabs. ${ }^{98}$

97. At this time, the general rules for issue and claim preclusive effect of federal judicial proceedings are entirely judge-made. See supra note 80 . The abstention cases are likewise largely the product of judicial imagination. See generally CHEMERINSKY, supra note 13, chs. 12-14. Habeas corpus also has a long history of court-drafted barriers to relief; some of them might reduce decision costs. See supra note 82.

98. Some of these arguments call into doubt existing due process doctrine. Although I will leave that issue to the reader, there could be meaningful differences between due and undue process claims. The most straightforward argument would be from constitutional text. Whatever else they mean, the Fifth and Fourteenth Amendments are widely read to impose process floors on government officials before (or after) they engi- 
Caveats are in order, however. Perhaps the judiciary need not be either shoved all the way into or pulled all the way out of undue process territory. Undue process claims might be softened by requiring courts to see clear error, or defer to the moreinformed judgment of other institutions. Either could reduce the threat of judicial mistakes. The breadth, not just the depth, of these claims could be moderated as well. We might identify particular instances of government decision-making when we are most confident that courts possess adequate competence along with healthy detachment. Some forms of administrative adjudication are the most plausible examples. In those cases, the decision-making process would be less foreign to the judiciary, while the institutional separation between agency and court presents a reason to trust judicial opinion at least as much as the officials responsible for the relevant process. On the other hand, excessive process seems less likely here-assuming that agencies cannot wholly externalize the costs of process for their own decisions.

In contrast, even moderated forms of undue process offer no stirring support for judicial control over judicial process. Obviously courts are best informed about the operations of their own institution. But they are also most likely to assume troubling parochial outlooks when someone complains that decisionmaking should be cut short. Process imposes costs on a large class of people, making it easy for the judiciary to appear sympathetic while serving lower-minded interests in docket clearing. In other words, courts might be habitually overexcited about undue process claims made within their own house. An independent judiciary can have clear advantages over other actors, but judging whether a case is too much work is probably not among them. Combined with democratic skepticism about unbridled judicial review, there is good reason to locate this problem of excessive decision costs in the category of ordinary law.

neer life, liberty, and property deprivations. This does not necessitate assertive judicial intervention, however, especially to run the decision-making processes of other institutions. Beyond text, one might try tradition, judicial precedent, the possible correlation with "fundamental" or otherwise disproportionately prized human values noted above, the possibly greater competence of courts in identifying abridgment of such values, and the chance that government is more likely to unjustifiably economize on its own decisionmaking than mandate extravagant efforts to reach a resolution-though discounted by the probability that courts will systematically underestimate the burdens of process in non-judicial operations. 


\section{CONCLUSION}

The Schiavo Act was exceptional and for many reasons it should stay that way. There probably were few actors less likely to make a sound decision about the merits of the case than the United States Congress. That said, the Act's modest objective was not plainly unconstitutional and a provisional theory of "undue process" suggests that Congress acted within its authority. The statute opened the federal courthouse for additional consideration of alleged rights violations, presenting the judiciary with more work on a matter of life, death, or something in between. Aversion to redundant litigation is a credible point in a policy debate, it is often reflected in sub-constitutional rules, and it is usually not a matter of fundamental law conjoined with judicial supremacy. But correctly assessing the validity of this particular statute is unimportant. What matters is rigorous and sustained thinking about how to locate the ceilings - not just the floors - of government process. 